\title{
Impact of water restriction periods on carcass traits and meat quality of feedlot lambs in the Brazilian semi-arid region
}

\author{
Fernanda Maria dos Santos ${ }^{\mathrm{a}}$, Gherman Garcia Leal de Araújo ${ }^{\mathrm{b}}$, Larissa Lopes de Souza ${ }^{\mathrm{c}}$, \\ Sandra Mari Yamamotoc,*, Mário Adriano Ávila Queiroz ${ }^{\mathrm{c}}$, Dante Pazzanese Duarte Lanna ${ }^{\mathrm{d}}$, \\ Salete Alves de Moraes ${ }^{\mathrm{b}}$ \\ ${ }^{a}$ Federal University of Bahia, CEP 40170-110 Salvador, Bahia, Brazil \\ ${ }^{\mathrm{b}}$ Brazilian Agricultural Research Corporation (EMBRAPA), CEP 56302-970 Petrolina, Pernambuco, Brazil \\ ${ }^{\mathrm{c}}$ Federal University of Vale do São Francisco, CEP 56310-770, Petrolina, Pernambuco, Brazil \\ ${ }^{\mathrm{d}}$ Luiz de Queiroz College of Agriculture, State University of São Paulo, CEP 13418-900, Piracicaba, São Paulo, Brazil
}

\section{A R T I C L E I N F O}

\section{Keywords:}

Fatty acids

Muscle

Water shortage

\begin{abstract}
A B S T R A C T
Water restriction periods were evaluated in crossbred lambs $(n=32)$ distributed in one of four treatments: without water restriction, water restriction for 24,48 and $72 \mathrm{~h}$. The water restriction for $72 \mathrm{~h}$ reduced the water and dry matter intakes, body weight at slaughter and hot and cold carcass yields. Water restriction did not affect the weight of the carcass cuts and the chemical composition of the meat. The fatty acid EPA increased and DHA reduced with increasing water restriction period. There was an increasing linear effect for meat shear force, with less force $\left(30.5 \mathrm{~N} / \mathrm{cm}^{2}\right)$ for sheep meat without water restriction and higher force $\left(45.8 \mathrm{~N} / \mathrm{cm}^{2}\right)$ for those with water restriction for $72 \mathrm{~h}$. The period of $24 \mathrm{~h}$ of water restriction was the one that promoted the highest similarities in the characteristics assessed to those in animals receiving water ad libitum. Therefore, water restriction periods should not exceed $24 \mathrm{~h}$ for feedlot animals in situations of severe water shortage.
\end{abstract}

\section{Introduction}

Water is an essential nutrient for animal production, but its availability is often a limiting factor for livestock in arid and semi-arid regions in the world (Alamer, 2010). In these regions, the animals mostly consume feed with low moisture content, low nutritional value and have irregular and limited access to water.

Sheep and goats can tolerate water shortage by activating some mechanisms to save this nutrient, which reduces the losses and increases the ability to withstand drought (Alamer, 2009). One mechanism to support low water availability is to reduce feed intake to lower the metabolic rate, which works as an adaptation to water conservation, since the animal will generate less heat in the digestive process, reducing the dissipation by evapotranspiration at high ambient temperatures (Maloiy et al., 2008). Furthermore, they tolerate loss of body water $>20 \%$ due to the ability of the rumen to store water (Jaber et al. 2004).

According to Barbour et al. (2005), although small ruminants in arid and semi-arid regions can survive up to a week with little or no water, the deficiency of this nutrient adversely affects the homeostasis, body weight, reproductive rate and disease resistance, besides the possibility of presenting negative impacts on the meat quality. However, there are few studies evaluating this practice of water management of animals in the Brazilian semi-arid region.

Thus, periods of water restriction alternating with water supply can be an alternative management to minimize the effects of water deficit in feedlot systems, in regions with water shortage. This study evaluates the effect of the water restriction period in Santa Inês crossbred sheep, through the evaluation of carcass traits, non-carcass components, yield of commercial cuts, physical and chemical characteristics and fatty acid profile of the Longissimus lumborum muscle.

\section{Material and methods}

\subsection{Locality, animals and diets}

All experimental procedures described in this work were approved by the Ethics Committee of Vale do São Francisco Federal University, with Protocol 0007/161012. The experiment was conducted at the Experimental Station of Caatinga, belonging to the Brazilian

\footnotetext{
* Corresponding author.

E-mail address: sandra.yamamoto@univasf.edu.br (S.M. Yamamoto).
} 
Table 1

Water supply and restriction periods during the experiment for crossbred Santa Inês lambs.

\begin{tabular}{lllll}
\hline Period & \multicolumn{4}{l}{ Tratament (hours water restriction) } \\
\cline { 2 - 5 } & 0 & 24 & 48 & 72 \\
\hline $\begin{array}{l}\text { Interval without water (days) } \\
\begin{array}{c}\text { Cumulative period with water access } \\
\text { (days) }\end{array}\end{array}$ & 0 & 1 & 2 & 3 \\
$\begin{array}{c}\text { Cumulative period without water access } \\
\text { (days) }\end{array}$ & 0 & 33 & 44 & 50 \\
Total time for data collection (days) & 67 & 67 & 67 & 67 \\
\hline
\end{tabular}

Agricultural Research Corporation - Embrapa, located in the municipality of Petrolina, Pernambuco, Brazil. During the experimental period (May to July 2013), the minimum and maximum average temperatures recorded were $21.97{ }^{\circ} \mathrm{C}$ and $31.22^{\circ} \mathrm{C}$, respectively, with relative air humidity of $60.52 \%$ and total rainfall of $22.2 \mathrm{~mm}$.

Thirty two Santa Ines crossbred lambs, with initial mean body weight of $20.7 \pm 2 \mathrm{~kg}$ and eight months of age were randomly assigned to one of four treatments: $\mathrm{T} 1=$ without water restriction (daily water supply); $\mathrm{T} 2=24 \mathrm{~h}$ of restriction and then water supply for $24 \mathrm{~h}$; $\mathrm{T} 3=48 \mathrm{~h}$ of restriction and then water supply for $24 \mathrm{~h}$ and $\mathrm{T} 4=72 \mathrm{~h}$ of restriction and then water supply for $24 \mathrm{~h}$, as shown in Table 1.

The lambs were housed individually in covered pens $(1 \times 2 \mathrm{~m})$, provided with feeders and drinkers. Each animal represented an experimental unit, constituting 8 replicates per treatment. The confinement lasted 77 days, 10 days for adaptation to diet, water supply and facilities and 67 days for data collection.

The diet offered to sheep was the same for all animals, composed of $50 \%$ Tifton grass hay and 50\% concentrate, consisting of $69.31 \%$ ground corn, $29.79 \%$ soybean meal and $0.9 \%$ mineral, formulated according to the requirements of the National Research Council (NRC, 2007) for daily weight gain of $200 \mathrm{~g}$. Nutrient and fatty acid composition of experimental diet is listed in Table 2 . The analyzes to estimate

Table 2

Nutrient and fatty acid composition of experimental diet.

\begin{tabular}{|c|c|c|c|}
\hline Variable & Tifton hay & Concentrate $^{\mathrm{b}}$ & Diet $(50: 50)^{c}$ \\
\hline \multicolumn{4}{|l|}{ Nutrient (g/kg DM) } \\
\hline Dry matter & 871.7 & 863.7 & 867.7 \\
\hline Organic matter & 911.0 & 970.5 & 940.7 \\
\hline Ether extract & 13.0 & 24.2 & 18.7 \\
\hline Crude protein & 125.6 & 204.8 & 165.2 \\
\hline $\mathrm{NDFcp}^{\mathrm{a}}$ & 688.6 & 97.3 & 392.9 \\
\hline Acid detergent fiber & 398.5 & 62.3 & 230.4 \\
\hline Non-fiber carbohydrates & 83.4 & 636.9 & 360.1 \\
\hline Lignin & 90.9 & 14.5 & 52.7 \\
\hline Total digestible nutrients & 599.3 & 838.9 & 719.1 \\
\hline \multicolumn{4}{|l|}{ Fatty acids $(\mathrm{g} / 100 \mathrm{~g})^{\mathrm{d}}$} \\
\hline Myristic (C 14:0) & 1.27 & 0.09 & - \\
\hline Palmitic (C 16:0) & 38.76 & 17.02 & - \\
\hline Margaric (C 17:0) & 0.66 & 0.09 & - \\
\hline Stearic (C 18:0) & 2.76 & 4.65 & - \\
\hline Arachidic (C 20:0) & 1.89 & 0.43 & - \\
\hline Behenic (C 22:0) & 2.28 & 0.22 & - \\
\hline Lignoceric (C 24:0) & 2.57 & 0.22 & - \\
\hline Palmitoleic (C 16:1:c9) & 0.57 & 0.11 & - \\
\hline Heptadecanoic (C 18:1c9) & 3.19 & 28.27 & - \\
\hline Vaccenic (C 18:1c11) & 0.91 & 2.65 & - \\
\hline Petroselinic (C 18:1c12) & 0.40 & 1.53 & - \\
\hline Linoleic C18:2c9c12 & 12.91 & 42.81 & - \\
\hline Linolenic C 18:3n3 & 20.44 & 1.05 & - \\
\hline
\end{tabular}

a Neutral detergent fiber corrected for ash and protein

b Was added to concentrate $0.9 \%$ of mineral supplement for sheep containing $136 \mathrm{~g}$ of sodium $/ \mathrm{kg}$

c Diet 50:50 (50\% hay and 50\% concentrate);

d $\%$ percentage of total fatty acids. the dry matter, organic matter, ether extract and crude protein were performed according to AOAC (2007). The neutral detergent fiber corrected for ash and protein (FDNcp) and acid detergent fiber were analyzed according to Van Soest, Robertson, and Lewis (1991) and nonfiber carbohydrates and total digestible nutrients according to Sniffen, O'Connor, Van Soest, Fox, and Russell (1992). The extraction of lipids followed the methodology proposed by Hara and Radin (1978) and the transesterification was performed according to Christie (1982). The results were expressed as percentage of total fatty acids.

\subsection{Dry matter and water intake}

The total diet was provided ad libitum, twice a day, at 8:00 h and 16:00 h, with leftovers previously collected and weighed every day to determine daily intake. Samples of the food provided and leftovers were collected weekly, by animal, which were stored in identified plastic bags and stored in a freezer. In these samples, the dry matter (DMI) analyses were carried out to determine the dry matter intake.

The water was supplied in containers of known volume, renewed twice a day and the leftovers measured. The water intake during performance (WIP) was estimated by calculating the difference between the amount of water offered and its surplus, discounting the water lost by evaporation. The WIP $(\mathrm{kg})$ was obtained by multiplying the water consumption by the number of days with access to water during the experimental period (WIP $\mathrm{T} 1=$ water consumption $\times 67$ days; WIP $\mathrm{T} 2=$ water consumption $\times 34$ days; $\quad$ WIP $\quad \mathrm{T} 3=$ water consumption $\times 23$ days, WIP T4 $=$ water consumption $\times 17$ days). To estimate the evaporation, buckets with water were distributed at strategic points in the shed, so that after weighing, this loss (evaportion) was added to the calculation of the WIP per animal.

The water intake via drinker (WID) was estimated by the difference between the amount of water supplied and the surplus and the daily evaporation of water (WID (kg/day) = water supplied - (surplus + evaporation)).

The production of metabolic water (MW) was estimated from the chemical analyses of the diets and calculated by multiplying the consumption of digestible carbohydrate, protein and ether extract by the factors 0.60; 0.42 and 1.10, respectively (Church, 1976; Taylor, Spinage, \& Lyman, 1969).

The water use efficiency was estimated by the ratio of water intake to dry matter intake (WI:DMI). Intake of water per $\mathrm{kg}$ of carcass produced (WI: kgCAR) was calculated using the relation between the water intake via the drinking fountain and the hot carcass weight.

\subsection{Slaughter and carcass traits}

After the confinement period, the lambs were weighed to obtain the final body weight (BW), and then subjected to solid fasting, receiving only water for $18 \mathrm{~h}$ and weighed again to obtain the body weight at slaughter (BWS). Next, the animals were stunned and slaughtered according to protocols established in Regulation of Industrial and Sanitary Inspection of Animal Products - RIISPOA (Brasil, 1997), and subsequently skinned, gutted and removed the head and the extremities of the limbs.

Weights of rumen-reticulum, omasum, abomasum, small and large intestine (full and empty), blood, skin, paws, spleen, liver (without gall bladder), heart, respiratory system and trachea, kidney, head and tongue, reproductive organs (penis and testicles) and empty bladder were also recorded.

Carcasses were weighed to obtain the hot carcass weight (HCW) and to determine the hot carcass yield (HCY). Subsequently, the carcasses were cooled at $4{ }^{\circ} \mathrm{C}$ for $24 \mathrm{~h}$, and weighed to obtain the cold carcass weight (CCW) and to calculate the cold carcass yield (CCY), cooling losses of the carcass (CLC) and true carcass yield (TCY) according to Cartaxo et al. (2009). The empty body weight (EBW) was calculated as BWS - gastrointestinal content. After cooling, morphometric 
measurements were taken on carcasses to calculate the carcass compactness indices $(\mathrm{CCI}(\mathrm{kg} / \mathrm{cm}))=\mathrm{CCW} /$ internal carcass length and leg compactness indices $(\mathrm{LCI})=$ rump width/leg length, according to Souza et al. (2013).

Carcasses were cut lengthwise to obtain the half-carcasses, which were weighed individually. The left half was cut into five anatomical regions: neck, shoulder, rib, loin and leg. In the dorsal portion of Longissimus lumborum (LL), at the level of the 13rd thoracic vertebra, measurements of maximum and minimum thickness of subcutaneous fat were taken, using a caliper. To determine the loin eye area (LEA), we used transparent paper to draw the area and then measured the area with the aid of the software Autocad.

\subsection{Meat quality measurements}

Loins of each carcass were identified, conditioned in plastic bags and frozen in a freezer at $-18^{\circ} \mathrm{C}$. After 7 days, loins were thawed for $10 \mathrm{~h}$ under refrigeration at $10^{\circ} \mathrm{C}$ and were dissected to separate the muscle, bone, subcutaneous fat, intermuscular fat and other tissues, which were individually weighed for calculation of yields. Muscle tissue was used to determine the moisture, crude protein and mineral matter contents, according to AOAC (2007) and the ether extract content was determined in an extractor device (ANKOM TX10), according to the methodology proposed by AOCS (2009).

The water holding capacity (WHC) was calculated by the filter paper press method (Hamm, 1986), and the result was expressed in percentage of water exuded compared to the initial sample weight $[$ WHC $(\%)=[($ final weight $\times 100) /$ initial weight $]$.

To determine the cooking losses (CL), a sample of $50 \mathrm{~g}$ in natura Longissimus lumborum muscle was used, free of visible connective tissue. Each sample was divided into 2 subsamples, weighing approximately $25 \mathrm{~g}$ and then wrapped in aluminum foil and grilled on plate preheated to $175^{\circ} \mathrm{C}$. The samples were turned over and the internal temperature of the meat was monitored through a digital spit thermometer until it reached $75{ }^{\circ} \mathrm{C}$ in the geometric center of the meat. Then, they were cooled at room temperature, taken out of foil and weighed again to calculate the cooking losses.

The following analysis evaluated the shear force (SF), where each sample of grilled meat was cut into two $1 \mathrm{~cm}^{2}$ cubes (totaling 4 replicates for each animal) in the direction of the muscle fibers, and then cut into a texture analyzer (TA-XT Express Texture Analyzer, Stable 165 Micro Systems, Godalming, UK) equipped with a Warner-Bratzler 166 shear force device $(2.00 \mathrm{~mm} / \mathrm{s}$ speed). To classify the meat texture, we adopted the interpretation of Cezar and Sousa (2007).

\subsection{Fatty acid profile}

The composition of the fatty acids present in the lipid extract was obtained using $7 \mathrm{~g}$ muscle tissue collected from the Longissimus lumborum muscle after dissection (removal of fascia, connective tissue, subcutaneous and intermuscular fat).

The extraction of total lipids from muscle tissue followed the methodology proposed by Hara and Radin (1978), and the transesterification was performed according to Christie (1982). Fatty acid methyl esters (FAME, \%) in meat were quantified was carried out by gas chromatography in a Thermo Finnigan Trace-GC Ultra equipment with a flame ionization detector (FID) and a capillary column CP-Sil 88 (Varian), $100 \mathrm{~m}$ in length, $0.25 \mu \mathrm{m}$ inner diameter, $0.20 \mu \mathrm{m}$ thick film. Hydrogen was used as the carrier gas at a flow rate of $1.8 \mathrm{ml} / \mathrm{min}$. The initial oven temperature program was $70^{\circ} \mathrm{C}, 4 \mathrm{~min}$ waiting time, $175^{\circ} \mathrm{C}$ $\left(13^{\circ} \mathrm{C} / \mathrm{min}\right) 27 \mathrm{~min}$ waiting time, $215^{\circ} \mathrm{C}\left(40^{\circ} \mathrm{C} / \mathrm{min}\right) 9 \mathrm{~min}$ waiting time and then increasing $7 \mathrm{C}^{\circ} / \mathrm{min}$ to $230^{\circ} \mathrm{C}$, remaining for $5 \mathrm{~min}$, totaling $65 \mathrm{~min}$. The vaporizer temperature was $250^{\circ} \mathrm{C}$ and that of the detector $300^{\circ} \mathrm{C}$, according to the temperature program described by Ribeiro et al. (2011).

An aliquot of $1 \mu \mathrm{l}$ esterified extract was injected into the chromatograph and the identification of individual fatty acids was performed by comparison of the retention times of the methyl esters presented by the Supelco TM Component FAME Mix chromatography standard (cat 18,919 Supelco, Bellefonte, PA). The fatty acids with cis and trans isomers were separated by chromatographic run along the $100 \mathrm{~mm}$ column. No specific treatment was performed for this, and the sample was extracted and esterified as a whole. The concentration of fatty acids was determined by the percentage of the area of a determined fatty acid when added to the areas of all the peaks present in the sample. The results were expressed as $\mathrm{g} / 100 \mathrm{~g}$ identified total fatty acid methyl esters.

The nutritional quality of the lipid fraction was evaluated by the composition data of fatty acids, using the calculations of atherogenicity index $(\mathrm{AI})=\{(\mathrm{C} 12: 0+(4 \times \mathrm{C} 14: 0)+\mathrm{C} 16: 0)\} / \Sigma \mathrm{AGMI}+\Sigma \omega 6+\Sigma$ $\omega 3)$ and thrombogenicity index (TI) $=(\mathrm{C} 14: 0+\mathrm{C} 16: 0+\mathrm{C} 18: 0) /$ $\{(0,5 \times \Sigma$ AGMI $)+(0,5 \times \Sigma \omega 6+(3 \times \Sigma \omega 3)+(\Sigma \omega 3 / \Sigma \omega 6)\}$ according to Ulbricht and Southgate (1991). AI indicates the risk of atherosclerosis and TI, the platelet aggregation.

\subsection{Statistical analysis}

The experiment was a completely randomized design with four treatments and eight replications. The mathematical model used was $Y_{i j}=\mu+H_{j}+e_{i j}$, where $Y_{i j}=$ value referring to observation of repetition "i" of treatment " $\mathrm{j}$ "; $\mu=$ overall mean; $\mathrm{H}_{\mathrm{j}}=$ effect of treatment "j" $(0,24,48$ and $72 \mathrm{~h}$ of restriction $)$ and $\mathrm{e}_{\mathrm{ij}}=$ random error associated with observation. The half carcass weight was used as covariate in the analysis of the carcass cuts.

The results were analyzed by the software Statistical Analysis System - SAS (version 9.1, 2003), with previous analysis of normality of the residuals by the Shapiro-Wilk test (PROC UNIVARIATE) and the variances compared by orthogonal contrasts (linear, quadratic and deviation from the quadratic model) with a significance level of $5 \%$ by PROC GLM. After analysis of contrasts, when significant, we determined the parameters of the regression equations using PROC REG.

\section{Results and discussion}

\subsection{Water intake and dry matter}

The animals that were subjected to water restriction during $72 \mathrm{~h}$ showed a reduction of $52.4 \%(P<0.05)$ in the total water intake (WIP) in relation to the animals that received water ad libitum during the experimental period (Table 3). Even observing an increase in daily water intake via drinker (WID) when it was available for animals with $72 \mathrm{~h}$ of restriction, the amount of water ingested did not compensate the amount consumed in the ad libitum group. This because the days of consumption were reduced, that is, the animals in the control group ingested water for 67 days, while the animals that underwent water restriction for $72 \mathrm{~h}$ only consumed water for 17 days.

The WIP of the animals with $24 \mathrm{~h}$ water restriction was $8.1 \%$ smaller compared to the control group. The animals with water restriction of $48 \mathrm{~h}$ presentend reduction of $34.8 \%$ in water intake. This demonstrates the similarity of the total water intake during the performance of the group without restriction with the group of animals with water restriction of $24 \mathrm{~h}$. Ruminant animals, particularly sheep, may survive the dehydration of up to $20 \%$, because of the capacity of the rumen in storing water, which can be used under low availability of this nutrient (Casamassima et al., 2008).

When water was available for the animals with restriction, WID (kg/ day) increased $(P<0.05)$ according to the increase in water restriction period. The mean consumption for animals that had free access to water was $3.43 \mathrm{~kg} /$ day. The sheep with water restriction of $72 \mathrm{~h}$ consumed $7.08 \mathrm{~kg}$, that is, $121 \%$ daily volume when compared to the animals with free access to drinking water. This is because, in an attempt to quench thirst, the animals ingest more in the first $60 \mathrm{~min}$ of access to 
Table 3

Dry matter and water intake by Santa Ines crossbred lambs submitted to different periods of water restriction.

\begin{tabular}{|c|c|c|c|c|c|c|c|}
\hline \multirow[t]{2}{*}{ Variable } & \multicolumn{4}{|c|}{ Water restriction $(\mathrm{h})$} & \multirow[t]{2}{*}{ SEM } & \multirow[t]{2}{*}{$\mathrm{R}^{2}$} & \multirow{2}{*}{$\begin{array}{l}P \text {-value } \\
\text { Lin. }\end{array}$} \\
\hline & 0 & 24 & 48 & 72 & & & \\
\hline DMI, kg/day ${ }^{1}$ & 0.93 & 0.93 & 0.74 & 0.65 & 36.38 & 49.58 & 0.0004 \\
\hline WIP, $\mathrm{kg}^{2}$ & 229.6 & 211.0 & 149.8 & 120.2 & 10.66 & 59.58 & $<0.0001$ \\
\hline $\begin{array}{l}\text { WID, kg/sheep/ } \\
\text { day }^{3}\end{array}$ & 3.43 & 6.21 & 6.51 & 7.08 & 0.32 & 60.00 & $<0.0001$ \\
\hline WIF, kg/day & 0.12 & 0.12 & 0.10 & 0.09 & 0.006 & - & 0.1043 \\
\hline MW (kg/day) ${ }^{4}$ & 0.51 & 0.47 & 0.38 & 0.37 & 0.013 & 74.42 & $<0.0001$ \\
\hline WI:DMI & 3.67 & 6.68 & 8.78 & 10.89 & 0.13 & 31.04 & 0.0023 \\
\hline $\mathrm{WI} / \mathrm{kgCAR}^{6}$ & 15.69 & 14.39 & 12.00 & 10.92 & 0.53 & 44.69 & $<0.0001$ \\
\hline
\end{tabular}

Dry matter intake (DMI);Water intake during performance (WIP); Water intake via drinker (WID); Water intake via food (WIF); Metabolic water (MW); Water intake: dry matter intake (WI:DMI); Water intake per $\mathrm{kg}$ carcass (WI/kg CAR); $\mathrm{SEM}=$ standard error of the mean; $\mathrm{R}^{2}=$ coefficient of determination; Lin: significance for linear effect. Significant at 5\% probability; RE = regression equation. $\quad$ RE. $^{1}$ : $\hat{\mathrm{Y}}=0.9647-0.427 \mathrm{x} ; \quad \mathrm{RE}^{2}$ : $\hat{\mathrm{Y}}=235.456-1.6099 \mathrm{x} ; \mathrm{RE}^{3}$ : $\hat{\mathrm{Y}}=4.0649+0.0473 \mathrm{x} ; \mathrm{RE}^{4}{ }^{4} \hat{\mathrm{Y}}=0.5125-0.00222 \mathrm{x} ;$ RE. $^{5}: \hat{\mathrm{Y}}=3.729-0.0137 \mathrm{x}$; RE. ${ }^{6}: \hat{Y}=15.74143-0.06911 x$.

the water. The animals with water restriction of $24 \mathrm{~h}$ consumed $14 \%$ more when compared to the animals that received water daily. In addition, when water was given ad libitum again, there was no sign of compensatory increase in food intake.

The extending the period of water restriction reduced the dry matter intake by $30 \%(P<0.05)$, of the group without water restriction compared to the one that with water restriction of $72 \mathrm{~h}(0.93$ and $0.65 \mathrm{~kg} /$ animal/day, respectively), inferring that, because of the unavailability of water, animals reduce this consumption. Due to periods of water unavailability, in the attempt to quench thirst, the animals ingested more water per day at the time of the supply, mainly the animals that spent three days without ingesting water, even consuming more than the animals with free access to water. This may have caused ruminal fill and, consequently, hypertonicity of the rumen-reticulum musculature caused by the accumulation of ingested water, reducing DMI. An abnormal prandial increase in ruminal fluid osmolality contributes to the suppression or reduction of food intake during water restriction (Burgos, Langhans, \& Senn, 2000). Despite a marked decrease in DMI of animals subjected to 48 and 72 hour-restriction, the DMI of animals with $24 \mathrm{~h}$ of water restriction was close to the intake of animals with daily access to water.

According to Alamer \& Al-hozab, 2004), the reduction in dry matter intake due to water restriction, is an adaptation mechanism to reduce costs related to the use of water in food digestion process, thus resulting in greater water conservation. This concomitantly reduces heat production (metabolism) and increases the water retention, sufficient to achieve a new equilibrium over a longer period of water restriction. Abioja, Osinowo, Adebambo, Bello, and Abiona (2010) explained that the reduction in dry matter intake from the water restriction can be the result of the need of water for moistening the bolus and transportation of the gastrointestinal tract content.

Despite the reduction in dry matter intake, there was no effect $(P>0.05)$ of the water restriction on water intake by food (WIF). However, there was a decreasing linear effect $(P<0.05)$ for MW $(\mathrm{kg} /$ day). Misra and Singh (2002) found no effect on metabolic water intake when subjected goats in semi-arid regions of India to $48 \mathrm{~h}$ of water restriction. Metabolic water is produced during the oxidation of the hydrogens contained in the main nutrients, with $1 \mathrm{~g}$ of protein, carbohydrate and fat producing $0.42 \mathrm{~g} ; 0.60 \mathrm{~g}$ and $1.10 \mathrm{~g}$ water for each nutrient, respectively (Church, 1976). With the reduction in DMI, the availability of nutrients for oxidation also reduced, then, there was a decrease of the water produced during the catabolism.

According to the NRC (2007), for each kilogram of dry matter
Table 4

Weight, yield and indices of Santa Ines crossbred lambs submitted to different periods of water restriction.

\begin{tabular}{|c|c|c|c|c|c|c|c|}
\hline \multirow[t]{2}{*}{ Variable } & \multicolumn{4}{|c|}{ Water restriction (h) } & \multirow[t]{2}{*}{ SEM } & \multirow[t]{2}{*}{$\mathrm{R}^{2}$} & \multirow{2}{*}{$\frac{\text { P-value }}{\text { Lin }}$} \\
\hline & 0 & 24 & 48 & 72 & & & \\
\hline BWS, kg ${ }^{1}$ & 32.62 & 32.29 & 26.77 & 25.88 & 0.89 & 66.80 & 0.0011 \\
\hline EBW, $\mathrm{kg}^{2}$ & 25.33 & 25.04 & 21.90 & 20.08 & 0.69 & 49.43 & 0.0015 \\
\hline $\mathrm{HCW}, \mathrm{kg}^{3}$ & 14.90 & 14.26 & 11.27 & 10.85 & 0.47 & 43.48 & 0.0051 \\
\hline CCW, $\mathrm{kg}^{4}$ & 14.32 & 13.76 & 10.76 & 10.45 & 0.46 & 42.87 & 0.0048 \\
\hline $\mathrm{HCY}, \%^{5}$ & 45.69 & 44.17 & 42.10 & 41.91 & 0.48 & 53.26 & 0.0007 \\
\hline $\mathrm{CCY}, \%^{6}$ & 43.91 & 42.62 & 40.23 & 40.38 & 0.46 & 54.65 & 0.0005 \\
\hline CCR, \% & 4.10 & 3.83 & 4.11 & 4.84 & 0.11 & - & 0.9848 \\
\hline TCY, \% & 54.89 & 56.19 & 56.62 & 50.10 & 0.45 & - & 0.6430 \\
\hline $\mathrm{CCI}, \mathrm{kg} / \mathrm{cm}^{7}$ & 0.23 & 0.24 & 0.21 & 0.20 & 0.005 & 73.28 & 0.0116 \\
\hline LCI & 0.62 & 0.60 & 0.62 & 0.62 & 0.008 & - & 0.7941 \\
\hline
\end{tabular}

BWS: body weight at slaughter; EBW: empty body weight; HCW: hot carcass weight; CCW: cold carcass weight; HCY: hot carcass yield; CCY: cold carcass yield; CCR: carcass cooling rate; TCY: true carcass yield; CCI: carcass compactness index; LCI: leg compactness index; SEM = standard error of the mean; $\mathrm{R}^{2}=$ coefficient of determination; Lin: significance for linear effect. Significant at $5 \%$ probability; $\mathrm{RE}=$ regression equation. $\mathrm{RE}^{1}{ }^{1}: \hat{\mathrm{Y}}=33.78782-0.1140 \times$; RE. ${ }^{2}: \hat{Y}=26.93913-0.09924 x ; \quad$ RE. $^{3}: \quad \hat{Y}=14.99189-0.0563 x ; \quad R^{4}{ }^{4}$ : $\hat{\mathrm{Y}}=14.42074 .0-0.05427 \mathrm{x} ; \quad$ RE. $^{5}: \quad \hat{\mathrm{Y}}=45.6435-0.0563 \mathrm{x} ; \quad$ RE. ${ }^{6}$ : $\hat{\mathrm{Y}}=44.007-0.0552 \mathrm{x} ;$ RE. $^{7}: 0.24923-0.00089744 \mathrm{x}$.

ingested, the animal should consume 2.871 of water. All animals had a higher intake than that recommended by the NRC (2007). According to this study, there was an increase $(P<0.05)$ in the ratio WI: DMI when the animals were subjected to different periods of water restriction, because, as the restriction periods increased, the animals consumed more water when it was available. The WI: DMI ratio of the animals that underwent water restriction of $24 \mathrm{~h}, 48 \mathrm{~h}$ and $72 \mathrm{~h}$ were 182.0 , 239.2 and $296.7 \%$, respectively, higher than the intake of animals that received water daily.

\subsection{Carcass traits}

The body weight at slaughter (BWS) decreased linearly $(P<0.05)$ with increasing periods of water restriction (Table 4). Studies on water restriction indicate that a part of the body weight reduction in ruminants is related to the combined effect of body water loss and decreased feed intake (Alamer, 2006, 2009; Hamadeh et al., 2006; Silanikove, 1992) or mobilization of fat for energy production to compensate for the lower feed intake (Jaber et al., 2004) during the water restriction periods. During this period, the body weight of the animals is reduced, also decreasing the requirement of nutrients. The BWS of the animals subjected to water restriction of $24 \mathrm{~h}$ was close to the BWS of the animals without water restriction, demonstrating that the deprivation of water for $24 \mathrm{~h}$ followed by $24 \mathrm{~h}$ of hydration did not affect the final weight of the animals.

The EBW, HCW and CCW decreased $(P<0.05)$ with increasing water restriction period. Prolonged periods of water restriction reduce the gastrointestinal passage rate, reducing body weight at slaughter and, consequently, empty body weight and hot carcass weight. The reduction in nutrient intake for animals may explain the observed decrease in body weight at slaughter, empty body weight, hot carcass weight and cold carcass weight, since these parameters reflect directly on the animal performance and are natural indicators of the ingestion of nutrient (Urbano et al., 2013). In the dry season, when food and water availability is limited, regression of productive indexes and animal performance may occur, reducing productivity (Ponnampalam et al., 2018). Tibin, Bushara, Elemam, Tibin, and Jadalla (2012) evaluated the sheep carcass traits in the desert, which were subjected to water supplies with intervals every 2-3 days, water ad libitum with and without supplementation in the diet, and found lower body weight at slaughter, hot carcass weight, half carcass and empty body weight for animals that 
had restricted access to water, corroborating data from this study.

In addition, the HCY and CCY decreased $(P<0.05)$ with increasing water restriction periods. This reduction can be explained by the decrease in BWS, HCW and CCW, due to reduction in nutrient supply. Although the observed decrease in HCY e CCY, the periods of the water restriction did not influence $(P>0.05)$ the TCY. Although the reduction of BWS, HCW, CCW, HCY e CCY with the water restriction, the group of animal with restriction every $24 \mathrm{~h}$ showed similar weights the group that was not submitted the water restriction.

The periods of the water restriction did not influence $(P>0.05)$ the cooling losses (CCR), with a mean value of $4 \%$. These losses can vary from 3.0 to $4.0 \%$, according to the uniformity of fat, sex, weight and chilling temperature (Reis et al., 2001). The CCR can be indicative of adequate fat cover and protection against cooling in the refrigeration chamber, thus avoiding shortening by cold and excessive loss of water from the meat (Safari, Fogarty, Ferrier, Hopkins, \& Gilmour, 2001).

The water restriction did not influence $(P>0.05)$ the TCY, with a mean value of $54 \%$. According to Sañudo and Sierra (1986), carcass yields range from 40 to $60 \%$, according to breed, crosses and breeding system. Therefore, the data obtained in this study are consistent with those described by these authors.

There was a reduction $(P<0.05)$ of the CCI as the water restriction periods increased. Compactness indices indicate the amount and/or storage capacity of meat in the carcass and leg, which decreased with increasing restriction, i.e. the carcasses had reduced capacity of storing tissues, which agrees with the weights of retail cuts. However, LCI was not affected $(P>0.05)$ by the water restriction periods.

There was a decrease $(P<0.05)$ in the ratio of water intake per kilogram carcass (IW/kg CAR), that is, the animals of the control group ingested 229.621 of water throughout the experimental period, to produce $13.88 \mathrm{~kg}$ carcass, while animals with $72 \mathrm{~h}$ of water restriction ingested $29.63 \mathrm{~L}$ to produce $10.04 \mathrm{~kg}$, i.e., less 199.991 of water, with difference of $3.84 \mathrm{~kg}$ carcass. The carcass production of the animals with water restriction for $72 \mathrm{~h}$ was similar to that of the animals receiving water every day, saving $200 \mathrm{l}$ of water, which would be feasible under conditions of water shortage for feedlot animals. With the increase of the water restriction periods, there was reduction in the dry matter intake and decrease in the weight at slaughter, however, it did not affect the deposition of fat in the carcass. Thus, it is suggested that water restriction reduces the energy metabolism to conserve water and compensate for the reduction in food intake. When water supply is limited, there is a close interrelation between the amount of dry matter consumed and the amount of water ingested, which is a consequence of the low relationship between energy and water intake (Silanikove, 1989).

\subsection{Carcass cuts and tissue composition}

The water restriction periods did not affect the HCW and the carcass cut weights $(P>0.05)$. However, when HCW was used as a covariate, there was a significant effect on carcass cut weights (Table 5).

The proportion of muscle did not differ $(P>0.05)$ as shown in Table 6 . This is related to the order of growth (estimated by allometry coefficients) of the muscle, which has an isometric development and evolves parallel to the growth of the carcass. These results confirm the anatomical harmony law of Boccard and Dumont (1960), according to which the relative proportions of the different body regions are similar in carcasses of similar weight and fattening.

The water restriction did not affect $(P>0.05)$ the proportion of subcutaneous fat, intermuscular fat, minimum (FTMin) and maximum (FTMax) fat thickness in relation to the loin. It was expected that the animals in the control group had the highest percentage of fat, since they have higher BWS and fat had a late development, but the water restriction did not affect this parameter. It has been reported that under a low nutritional level, the priority of nutrient supply for each part of the body depends on its rate of development and metabolic rate (Atti,
Table 5

Weight of carcass cuts of Santa Ines crossbred lambs submitted to different periods of water restriction.

\begin{tabular}{|c|c|c|c|c|c|c|c|c|}
\hline \multirow{2}{*}{$\begin{array}{l}\text { Variable } \\
(\mathrm{kg})\end{array}$} & \multicolumn{4}{|c|}{ Water restriction $(\mathrm{h})$} & \multirow[t]{2}{*}{ SEM } & \multirow[t]{2}{*}{$\mathrm{R}^{2}$} & \multicolumn{2}{|l|}{ P-value } \\
\hline & 0 & 24 & 48 & 72 & & & HOURS & $\mathrm{HCM}^{1}$ \\
\hline $\mathrm{HCW}$ & 7.11 & 7.05 & 6.18 & 5.65 & 0.22 & 72.57 & NS & 0.0001 \\
\hline $\mathrm{Leg}^{2}$ & 2.31 & 2.29 & 2.03 & 1.94 & 0.07 & 66.23 & NS & 0.0001 \\
\hline Loin $^{3}$ & 0.62 & 0.65 & 0.49 & 0.49 & 0.03 & 64.58 & NS & 0.0001 \\
\hline $\mathrm{Rib}^{4}$ & 1.92 & 1.94 & 1.53 & 1.48 & 0.07 & 72.64 & NS & 0.0001 \\
\hline Shoulder ${ }^{5}$ & 1.28 & 1.27 & 1.13 & 1.08 & 0.03 & 80.70 & NS & 0.0001 \\
\hline $\mathrm{Neck}^{6}$ & 0.56 & 0.60 & 0.53 & 0.46 & 0.02 & 54.38 & NS & 0.0001 \\
\hline
\end{tabular}

HCW = half carcass weight; SEM = standard error of the mean; Significant at $5 \%$ probability; $1 \mathrm{HCM}$ : half carcass weight as a covariate; NS: not significant.

\section{Table 6}

Tissue composition, loin measurements and physical and chemical characteristics of meat from Santa Ines crossbred lambs submitted to different periods of water restriction.

\begin{tabular}{|c|c|c|c|c|c|c|c|}
\hline \multirow[t]{2}{*}{ Variable } & \multicolumn{4}{|c|}{ Water restriction $(\mathrm{h})$} & \multirow[t]{2}{*}{ SEM } & \multirow[t]{2}{*}{$\mathrm{R}^{2}$} & \multirow{2}{*}{$\frac{\text { P-value }}{\text { Lin }}$} \\
\hline & 0 & 24 & 48 & 72 & & & \\
\hline Muscle, \% & 49.81 & 47.58 & 53.11 & 54.35 & 1.05 & - & 0.1032 \\
\hline Subcutaneous fat, \% & 10.88 & 9.88 & 11.17 & 8.92 & 0.56 & - & 0.3606 \\
\hline Intermuscular fat, \% & 3.77 & 3.50 & 3.95 & 3.71 & 0.26 & - & 0.9159 \\
\hline Bone, \% & 22.26 & 26.79 & 17.55 & 21.36 & 0.99 & - & 0.1170 \\
\hline Others, \% & 11.21 & 11.73 & 11.38 & 10.75 & 0.31 & - & 0.5423 \\
\hline FTMin, mm & 1.58 & 1.18 & 1.18 & 1.16 & 0.13 & - & 0.2774 \\
\hline FTMax, mm & 5.54 & 5.36 & 5.27 & 5.21 & 0.33 & - & 0.7290 \\
\hline Loin eye area, $\mathrm{cm}^{2}$ & 10.01 & 8.12 & 8.43 & 8.98 & 0.29 & - & 0.4897 \\
\hline WHC, $\%$ & 68.91 & 66.79 & 66.23 & 65.99 & 0.64 & - & 0.1066 \\
\hline CL, \% & 27.96 & 30.65 & 30.03 & 30.72 & 0.65 & - & 0.1429 \\
\hline $\mathrm{SF}\left(\mathrm{N} / \mathrm{cm}^{2}\right)^{1}$ & 30.50 & 30.79 & 38.15 & 45.79 & 0.25 & 60.29 & 0.0055 \\
\hline Water, $\%$ & 75.00 & 75.00 & 76.00 & 75.00 & 0.39 & - & 0.8492 \\
\hline Crude protein, \% & 20.89 & 21.01 & 20.08 & 21.41 & 0.23 & - & 0.7589 \\
\hline Ether extract, \% & 2.31 & 3.80 & 2.00 & 1.97 & 0.41 & - & 0.4451 \\
\hline Mineral matter, \% & 1.12 & 1.19 & 1.13 & 1.11 & 0.02 & - & 0.6181 \\
\hline
\end{tabular}

FTMin = minimum fat thickness; $\quad$ FTMax = maximum fat thickness; WHC = water holding capacity; $\mathrm{CL}=$ cooking losses; SF = Warner-Bratzler shear force; SEM = standard error of the mean; $\mathrm{R}^{2}=$ coefficient of determination; RE. ${ }^{1}: \hat{\mathrm{Y}}=28.52+0.0222 \mathrm{x}$, Lin: significance for linear effect. Significant at $5 \%$ probability.

Mahouachi, \& Rouissi, 2006; Kamalzadeh, Koops, Van Bruchem, \& Brangma, 1998).

However, there was no effect $(P>0.05)$ for bone percentage in the loin, with a mean value of $22 \%$. Bone is an early maturing tissue and at 8 months (growing animals) is less affected by diet. For tissue composition, muscle yield was superior to other tissues. Possibly, the highest percentage of muscle over fat and bones, in the analyzed cut, was influenced by the age of the animals, which were young (eight months).

There was no effect $(P>0.05)$ for loin eye area with water restriction, with a mean value of $8.93 \mathrm{~cm}^{2}$. The Longissimus lumborum muscle has late development, thus, the young age of the animals would justify the values found. This result was not to expected, once the reduction in water consumption decreases DM intake and, consequently, the supply of nutrients, mainly of protein for the muscular development.

\subsection{Meat physical and chemical parameters}

The water holding capacity (WHC) was not influenced by the water restriction, with a mean value of $67 \%$ (Table 6 ). The WHC of meat is the ability of retaining water during the application of external forces and affects the juiciness at the time of consumption (Henchion et al. 2014). In addition, it has great importance in storage and shelf life of the product. Possibly, the water restriction of up to $72 \mathrm{~h}$ did not affect the 
$\mathrm{pH}$ of the postmortem muscle, and consequently, the isoelectric point of proteins (Munasinghe \& Sakai, 2004) maintaining the meat ability to hold water.

The water restriction periods did not influence $(P>0.05)$ the cooking losses, with a mean value of $29.84 \%$. However, SF increased according to the extended period of water restriction. Meat of the animals with water restriction for $24 \mathrm{~h}$ had SF of $30.8 \mathrm{~N} / \mathrm{cm}^{2}$, classified as medium tenderness $\left(22.4\right.$ to $35.6 \mathrm{~N} / \mathrm{cm}^{2}$ ). The water restriction for 48 and $72 \mathrm{~h}$ resulted in meat with SF of $38.1 \mathrm{~N} / \mathrm{cm}^{2}$ and $45.8 \mathrm{~N} / \mathrm{cm}^{2}$, respectively, classified as hard ( 35.7 to $53.4 \mathrm{~N} / \mathrm{cm}^{2}$ ), following the scale suggested by Cezar and Sousa (2007).

These results can be explained by the fact that animals that were subjected to a longer period of water restriction suffered from preslaughter stress. In addition, there was a reduction in food intake, which have reduced glycogen storage in the muscle. In stress conditions, there is an increased glycolytic activity, rapid protein denaturation, accelerating the rigor mortis process, making the meat of the animals tougher (Carragher \& Matthews, 1996). No other published study to our knowledge provides a comparison on the effect of water restriction on meat tenderness.

The determination of water content in meat is one of the most important measures used in food analysis, since it is related to its composition, stability and quality, and can influence the storage, packaging and processing (Jiménez Colmenero, 1996), moreover exerts influence on carcass dressing. Nevertheless, the water content in the LL muscle was not influence $(P>0.05)$ by water restriction, with mean value of $75 \%$, corroborating Madruga et al. (2008), which stated that the sheep meat has about $73 \%$ moisture.

The contents of crude protein, fat and minerals in meat were not affected $(P>0.05)$ by water restriction with mean values of $21 ; 2$ and $1 \%$, respectively. According to Zeola, Silva Sobrinho, Gonzaga Neto, and Marques (2004), the average protein in sheep meat is $19 \%$, ether extract is $2 \%$ and mineral matter is $1 \%$, values similar to those found herein. Thus, different periods of water restriction had no influence on the chemical composition of LL muscle of animals.

\subsection{Non-carcass components}

The water restriction did not influence the head weight $(P<0.05)$, suggesting that the growth pattern is related to the coefficient of allometry, in which the bone growth is intermediate (Rosa, Pires, Silva, \& Motta, 2002), occurring in the initial growth phase and is less affected by diet (Table 7).

The weights of the paws linearly decreased $(P<0.05)$ with increasing of water restriction period. Despite having an early development, the weight of paws reduced possibly due to the decrease the dry matter intake, due to the reduced interval of water supply, inferring the need for nutritional support for development.

The rumen-reticulum weight decreased $(P<0.05)$ with longer periods of water restriciton, which is explained by the reduction of DMI and water, which may have caused less developed and distention of the organ. Kremer, Lorenzi, and Barbato (1989) also mentioned that the development of the rumen-reticulum is related to the animal weight, corroborating this study. Therefore, animals with longer interval of water restriction had lower body weight at slaughter, which reinforces the fact that the lack of water has caused lower food intake, the development and the distension of these organs.

Water supply intervals did not affect $(P>0.05)$ the weight of omasum, abomasum, small and large intestine, blood, spleen, heart, head and tongue and bladder. Drouillard et al. (1991) reported that these organs of importance to the animal are proportionally larger at birth and, consequently, develop less in postnatal life.

The skin, due to the good softness and elasticity, is the most important non-carcass component, reaching $10 \%$ of the animal value; however, there was a reduction $(P<0.05)$ in weight by $23 \%$. The reproductive organs $(\mathrm{RO})$ decreased linearly $(P<0.05)$ by 24 and
Table 7

Non-carcass components of Santa Ines crossbred lambs submitted to different periods of water restriction.

\begin{tabular}{|c|c|c|c|c|c|c|c|c|}
\hline \multirow{2}{*}{$\begin{array}{l}\text { Variable } \\
(\mathrm{kg})\end{array}$} & \multicolumn{4}{|c|}{ Water restriction (h) } & \multirow[t]{2}{*}{ SEM } & \multirow[t]{2}{*}{$\mathrm{R}^{2}$} & \multicolumn{2}{|l|}{$\mathrm{P}$-value } \\
\hline & 0 & 24 & 48 & 72 & & & Lin & Quad \\
\hline $\mathrm{RR}^{1}$ & 0.76 & 0.78 & 0.69 & 0.61 & 0.02 & 42.06 & 0.0016 & 0.1432 \\
\hline Omasum & 0.09 & 0.13 & 0.07 & 0.19 & 0.03 & - & 0.3936 & 0.5250 \\
\hline Abomasum & 0.15 & 0.17 & 0.15 & 0.16 & 0.007 & - & 0.9799 & 0.6359 \\
\hline SI & 0.82 & 0.82 & 0.76 & 0.77 & 0.03 & - & 0.5112 & 0.9404 \\
\hline LI & 0.23 & 0.22 & 0.18 & 0.21 & 0.01 & - & 0.3376 & 0.2872 \\
\hline Blood & 0.95 & 1.07 & 0.78 & 0.79 & 0.04 & - & 0.0621 & 0.5450 \\
\hline Skin $^{2}$ & 2.70 & 2.80 & 2.54 & 2.08 & 0.09 & 42.41 & 0.0058 & 0.0946 \\
\hline Spleen & 0.05 & 0.06 & 0.05 & 0.04 & 0.002 & - & 0.1556 & 0.0957 \\
\hline Liver $^{3}$ & 0.53 & 0.49 & 0.44 & 0.40 & 0.02 & 65.30 & 0.0033 & 0.9783 \\
\hline Heart & 0.12 & 0.12 & 0.11 & 0.11 & 0.04 & - & 0.1628 & 0.6959 \\
\hline RSTE $^{4}$ & 0.57 & 0.57 & 0.51 & 0.44 & 0.01 & 47.95 & 0.0032 & 0.3078 \\
\hline Kidneys $^{5}$ & 0.08 & 0.09 & 0.08 & 0.07 & 0.02 & 52.22 & 0.0770 & 0.0002 \\
\hline $\mathrm{H}+\mathrm{T}$ & 1.51 & 1.55 & 1.43 & 1.38 & 0.04 & - & 0.1717 & 0.5684 \\
\hline Paws $^{6}$ & 0.74 & 0.75 & 0.66 & 0.57 & 0.02 & 55.31 & $<0.001$ & 0.3906 \\
\hline $\mathrm{RO}^{7}$ & 0.37 & 0.33 & 0.27 & 0.28 & 0.01 & 24.69 & 0.0161 & 0.4465 \\
\hline Bladder & 0.02 & 0.01 & 0.01 & 0.01 & 0.002 & - & 0.2293 & 0.2918 \\
\hline
\end{tabular}

$\mathrm{RR}=$ rumen-reticulum; $\quad \mathrm{SI}=$ small $\quad$ intestine; $\quad \mathrm{LI}=$ large $\quad$ intestine; RSTE = respiratory system, trachea and esophagus; $\mathrm{H}+\mathrm{T}=$ head and tongue; $\mathrm{RO}=$ reproductive organs (penis and testicles); SEM = standard error of the mean; $\mathrm{R}^{2}=$ coefficient of determination; Lin: significance for linear effect. Quad: significance for quadratic effect. Significant at $5 \%$ probability; $\mathrm{RE}=$ regression $\quad$ equation; $\quad$ RE. $^{1}: \quad \hat{\mathrm{Y}}=0.7957-0.0023 \mathrm{x} ; \quad$ ER. $^{2}$ : $\hat{\mathrm{Y}}=2.7766-0.01125 \mathrm{x} ; \quad \mathrm{ER}^{3}{ }^{3}: \quad \hat{\mathrm{Y}}=0.55234-0.00237 \mathrm{x} ; \quad$ ER. $^{4}: \quad \hat{\mathrm{Y}}=0.58879$ $-0.0025 x ; \quad E^{5}{ }^{5}: \quad Y=0.07735+0.000608 x-0.0000099 x^{2} ; \quad E^{6}{ }^{6}$ : $\hat{\mathrm{Y}}=0.7737-0.00278 \mathrm{x} ; \mathrm{ER} .^{7}: \hat{\mathrm{Y}}=0.3661-0.1453 \mathrm{x}$.

$28 \%$, respectively. Both the skin and the reproductive organs presented isogonic growth, that is, the growth rate was similar to EBW.

There was a $23 \%(P<0.05)$ reduction in the weight of respiratory system and trachea (RSTE). During periods of water shortage, some physiological mechanisms are activated, such as reduction of respiratory rate, resulting in decreased water losses (Alamer, 2009), as a way to save this nutrient. The weight of the RSTE was possibly reduced as the water restriction period increased in response to the low water intake and consequently the lower respiratory rate in an attempt to reduce the water removed during respiration.

The increase in the period of water restriction promoted a reduction $(P<0.05)$ in liver weight, which is important for various metabolic processes, especially for energy and protein metabolism, reducing $17 \%$ at $72 \mathrm{~h}$ of water restriction compared to daily supply. Liver and kidneys are priority organs in animal metabolism and the reduction in liver may be indicative of the reduction of metabolic rate, since the water consumption promoted reduction in dry matter intake (Camilo et al., 2012), with a notable atrophy for receiving feed below the maintenance level.

There was a quadratic effect $(P<0.05)$ for the weight of the kidneys of sheep, with the highest value for lambs subjected to $24 \mathrm{~h}$ of water restriction. When there is water deficit, there is stimulation of antidiuretic hormone (ADH) secretion, which increases water reabsorption in renal collecting tubules. This mechanism also activates the thirst center, increasing water intake, increasing activity on renal flow and thus stimulating the growth, providing greater weight (Naves, Vilar, Costa, Domingues, \& Casulari, 2003).

The water restriction period did not influence $(P>0.05)$ the volume of the blood of animals, even with restriction of $72 \mathrm{~h}$, this must have occurred because the initial response of the body to the negative balance of water is the retention of body fluids (Kaliber, Koluman, \& Silanikove, 2015), maintaining constant blood volume of the animals. It is emphasized the importance of studies on these components, because some of them serve as food for the human population, such as the head, liver, heart, kidneys, lungs and digestive tract (Osório, Oliveira, Osório, 
Table 8

Fatty acids of Longissimus lumborum muscle (\% of total fatty acids) of lambs submitted to different periods of water restriction.

\begin{tabular}{|c|c|c|c|c|c|c|c|}
\hline \multirow[t]{2}{*}{ Variable } & \multicolumn{4}{|c|}{ Water restriction (h) } & \multirow[t]{2}{*}{ SEM } & \multirow[t]{2}{*}{$\mathrm{R}^{2}$} & \multirow{2}{*}{$\begin{array}{l}\text { P-value } \\
\text { Lin }\end{array}$} \\
\hline & 0 & 24 & 48 & 72 & & & \\
\hline$\Sigma$ SFA & 43.87 & 43.93 & 44.80 & 45.98 & 0.47 & - & 0.0810 \\
\hline Caproic (C10:0) & 0.35 & 0.36 & 0.26 & 0.36 & 0.019 & - & 0.6211 \\
\hline Lauric (C12:0) & 0.16 & 0.16 & 0.12 & 0.14 & 0.009 & - & 0.1958 \\
\hline Myristic (C14:0) & 2.00 & 2.00 & 2.00 & 2.00 & 0.054 & - & 0.8938 \\
\hline $\begin{array}{c}\text { Pentadecanoic } \\
\text { (C15:0) }\end{array}$ & 0.25 & 0.26 & 0.27 & 0.25 & 0.006 & - & 0.7891 \\
\hline Palmitic (C16:0) & 23.00 & 22.00 & 23.00 & 23.00 & 0.356 & - & 0.8562 \\
\hline Margaric $(\mathrm{C} 17: 0)^{1}$ & 0.59 & 0.65 & 0.70 & 0.70 & 0.012 & 45.35 & 0.0008 \\
\hline $\begin{array}{l}\text { Isomargaric } \\
\text { (C17:0iso) }\end{array}$ & 0.23 & 0.22 & 0.21 & 0.23 & 0.014 & - & 0.9766 \\
\hline Stearic (C18:0) & 17.00 & 18.00 & 18.00 & 19.00 & 0.418 & - & 0.0731 \\
\hline Behenic (C22:0) & 0.15 & 0.14 & 0.11 & 0.14 & 0.012 & - & 0.6556 \\
\hline$\Sigma$ UFA & 46.36 & 46.39 & 46.38 & 44.35 & 0.47 & - & 0.0810 \\
\hline $\begin{array}{l}\text { Palmitoleic } \\
\qquad \text { (C16:1c9) }\end{array}$ & 2.00 & 2.00 & 2.00 & 2.00 & 0.097 & - & 0.1341 \\
\hline Oleic (C18:1c9) & 41.00 & 41.00 & 41.00 & 38.00 & 0.782 & - & 0.1287 \\
\hline $\begin{array}{l}\text { Vaccenic } \\
\qquad(\mathrm{C} 18: 1 \mathrm{t} 11)^{2}\end{array}$ & 2.00 & 2.00 & 2.00 & 3.00 & 0.169 & 51.38 & 0.0006 \\
\hline $\begin{array}{l}\text { Petroselinic } \\
\qquad(\mathrm{C} 18: 1 \mathrm{c} 12)\end{array}$ & 1.00 & 1.00 & 1.00 & 1.00 & 0.073 & & 0.0754 \\
\hline$\Sigma$ PUFA & 8.86 & 7.78 & 7.76 & 7.79 & 0.62 & - & 0.8583 \\
\hline $\begin{array}{l}\text { Linoleic } \\
\qquad(\mathrm{C} 18: 2 \mathrm{c} 9 \mathrm{c} 12)\end{array}$ & 5.00 & 5.00 & 5.00 & 5.00 & 0.353 & - & 0.9038 \\
\hline CLA $(\mathrm{C} 18: 2 \mathrm{c} 9 \mathrm{t} 11)^{3}$ & 0.27 & 0.21 & 0.19 & 0.15 & 0.018 & 63.11 & 0.0002 \\
\hline $\begin{array}{l}\text { Linolenic } \\
\qquad(\mathrm{C} 18: 3 \mathrm{n} 3)\end{array}$ & 0.33 & 0.28 & 0.27 & 0.29 & 0.018 & - & 0.5391 \\
\hline $\mathrm{AA}(\mathrm{C} 20: 4 \mathrm{n6})$ & 3.00 & 2.00 & 2.00 & 2.00 & 0.274 & - & 0.7125 \\
\hline EPA $(C 20: 5 n 3)^{4}$ & 0.23 & 0.26 & 0.28 & 0.34 & 0.011 & 42.18 & $<0.0001$ \\
\hline DHA $(C 22: 5)^{5}$ & 0.03 & 0.03 & 0.02 & 0.01 & 0.001 & 52.80 & $<0.0001$ \\
\hline SFA:UFA & 0.75 & 0.79 & 0.82 & 0.82 & 0.02 & - & 0.0935 \\
\hline$\omega 6$ & 5.02 & 4.68 & 4.35 & 5.07 & 0.31 & - & 0.8144 \\
\hline$\omega 3$ & 0.32 & 0.28 & 0.26 & 0.29 & 0.17 & - & 0.5402 \\
\hline$\omega 6: n 3$ & 15.60 & 16.93 & 16.68 & 17.43 & 0.52 & - & 0.1038 \\
\hline $\mathrm{AI}$ & 0.54 & 0.56 & 0.56 & 0.56 & 0.01 & - & 0.7134 \\
\hline TI & 1.40 & 1.47 & 1.53 & 1.53 & 0.03 & - & 0.0832 \\
\hline h:H & 2.03 & 2.01 & 1.96 & 1.92 & 0.04 & - & 0.3496 \\
\hline
\end{tabular}

CLA (conjugated linolenic acid); AA (Aracdonic acid); EPA (eicosapentaenoic acid); C22:5 (docosapentaenoic acid); $\Sigma$ SFA: sum of saturated fatty acids; IMUFA: sum of monounsaturated fatty acids; $\Sigma$ UFA: sum of unsaturated fatty acids; $\Sigma$ PUFA: sum of polyunsaturated fatty acids; $\omega 6$ : omega 6; $\omega 3$ : omega 3; AI: atherogenicity index; TI: thrombogenicity index; DFA: desirable fatty acids; h:H: hypocholesterolemic: hypercholesterolemic fatty acids ratio $\mathrm{SEM}=$ standard error of the mean; $\mathrm{R}^{2}=$ coefficient of determination; Lin: significance for linear effect. Significant at $5 \%$ probability; Regression equation $(\mathrm{RE})^{1}: \quad \hat{\mathrm{Y}}=0.619+0.00095 \mathrm{x} . \quad \mathrm{RE}^{2}: \quad \hat{\mathrm{Y}}=1.684+0.0222 \mathrm{x} ; \quad \mathrm{RE} .^{3}$ : $\hat{\mathrm{Y}}=0.25018-0.00212 \mathrm{x} ; \quad \mathrm{RE}^{4}{ }^{4}: \quad \hat{\mathrm{Y}}=0.2229-0.00152 \mathrm{x} ; \quad$ RE. $^{5}: \quad \hat{\mathrm{Y}}=0.0336$ $-0.0002283 \mathrm{x}$.

Jardim, \& Pimentel, 2002).

\subsection{Fatty acid profile}

Regarding the profile of saturated fatty acids of meat, the water restriction period did not affect $(P>0.05)$ the percentage capric (C10:0), lauric (C12:0), myristic (C14:0), pentadecanoic (C15:0), palmitic (C16:0), stearic (C18:0) and behenic (C22:0) acids (Table 8).

The palmitic (C16:0) and stearic (C18:0) acids were the most prevalent in the lipid profile of meat as to total saturated fatty acids. This was due to the higher concentration of these fatty acids in the diet. The medium chain fatty acids such as myristic (C14:0) and palmitic (C16:0), considered hypercholesterolemic can increase both the total cholesterol concentration in the plasma and raise low density lipoprotein (LDL). While larger chain fatty acids such as stearic (C18:0), they are considered to be neutral for plasma cholesterol (Scollan et al., 2001).

No effect $(P>0.05)$ of water restriction was detected on the percentage of monounsaturated fatty acids, with mean values of 39 and $1 \%$ of C18:1c9 and C18: $1 \mathrm{c12}$, respectively. Among the unsaturated, it is verified a greater amount of C18:1c9 acid, which varies between 30 and $43 \%$ (Sañudo et al., 2000), confirming this study. Oleic acid, recognized for the hypocholesterolemic effect, was the monounsaturated fatty acid with the highest percentage, as observed by Sañudo et al. (2000), who mentioned that this acid ranges from 30 to $43 \%$ in lipid profile of the meat.

The increase in the water restriction period provided an increase $(P<0.05)$ in the vaccenic acid $(\mathrm{C} 18: 1$ trans11). The water restriction decreased dry matter intake and possibly reduced the population of bacteria responsible for ruminal biohydrogenation. Thus, there was a reduction in the conversion of unsaturated fatty acids, from the diet, into saturated, increasing the concentration of vaccenic acid, intermediate of biohydrogenation, in the rumen. After absorption by the small intestine of the animal, C18: 1 trans11 is deposited in muscle tissue (Van Nevel \& Demeyer, 1996). Vaccenic acid is an important precursor in the intermediary metabolism of conjugated linoleic acid (CLA), responsible for approximately 90\% CLA of the intramuscular fat of the meat (Nuernberg et al. 2002) Thus, it is expected that the increase in the vaccenic acid content will increase the amount of CLA in the meat, which was not verified in the present study.

The increase in the water restriction period resulted in a reduction $(P<0.05)$ of CLA in sheep meat. Vaccenic acid is transformed into CLA in ruminant muscle tissue through the action of the enzyme delta9-desaturase (Smith, Gill, Lunt, \& Brooks, 2009). Thus, reductions in water and dry matter, possibly have inhibited the messenger RNA synthesis of the delta-9 desaturase enzyme (Baumgard, Sangster, \& Bauman, 2001; Park et al., 2000) and, therefore, the conjugated linoleic acid, decreasing its abundance in the muscle tissue of animals with less access to water. This is not satisfactory in view of the beneficial properties of this acid due to nutraceutical properties. In addition, this fatty acid presents anticancer and beneficial effects to cardiovascular health (Tapiero, Nguyen Ba, \& Couvreur, 2002).

EPA and DHA have several cellular functions, are precursors of eicosanoids (prostaglandins, thromboxanes and leukotrienes) that have great importance in cardiovascular health. Moreover, they are essential for maintaining the integrity of the cell membrane and are important mediators of gene expression (Clarke, 2001). There was an increasing linear effect $(P<0.05)$ of EPA with the water restriction and a decreasing linear effect $(P<0.05)$ of DHA with the increase in water restriction. The lowest values were found in the meat of animals subjected to $72 \mathrm{~h}$ of restriction. EPA is formed by desaturation and stretching of $\alpha$-linolenic acid (Smith, 2007), so the reduction in feed intake caused by the reduction in water intake probably induced the synthesis of the enzyme delta 6 desaturase and elongases required for conversion of alpha-linolenic into its long chain derivatives (Pawlosky et al., 2003). Increasing EPA incorporation into cell membrane phospholipids results in increased production of eicosanoids that have antiinflammatory characteristics (Calder, 2006). Despite the increasing linear effect for EPA, DHA was reduced in the meat of animals subjected to 48 and $72 \mathrm{~h}$ of restriction, indicating that after this restriction period, there was probably a reduction in the synthesis of enzymes required for the conversion of linolenic acid into DHA, as well as specific transport mechanisms for these fatty acids in muscle tissue. DHA is the most important for proper cell membrane function and is vital for the development of the brain and retina (Ramakrishnan et al., 2010).

There was no effect for the sum of saturated (44.14\%), unsaturated (55.85\%), monounsaturated $(47.46 \%)$, polyunsaturated $(8.39 \%)$ fatty acids and SFA: UFA ratio. Dietary fatty acids are affected by rumen microorganisms, especially with respect to polyunsaturated fatty acids, with effects on the content and composition of fatty acids in the muscle. However, the water restriction up to $72 \mathrm{~h}$ did not affect the sum of these fatty acids. The $\omega 6 / \omega 3$ ratio was not affected $(P>0.05)$ by the water restriction period up to $72 \mathrm{~h}$. The SFA: UFA and $\omega 6: \omega 3$ ratios are used to evaluate the nutritional value of oils and fats and to indicate the cholesterolemic potential. There was no effect $(P>0.05)$ for AI, IT and 
the h: $\mathrm{H}$ ratio. These results corroborate the effect reported in this study for the muscle ether extract (Table 6), which showed no interaction with the water restriction.

\section{Conclusions}

Water restriction up to $72 \mathrm{~h}$ reduces water intake and dry matter intake, and consequently body weight and carcass yield. However, the final body weight and carcass yield of the animals subjected to $24 \mathrm{~h}$ of restriction was similar to the weight of the animals that received water daily. The weight of the meat cuts was not affected by water deprivation, as well as the tissue and chemical composition of the Longissimus lumborum muscle. The weight of non-carcass components commercially valued as the rumen-reticulum, skin and liver reduced with the water restriction, however, the weights of these were similar between the 24$\mathrm{h}$ group and the group with free access to water deprivation. The highest weight of the kidneys of lambs was observed in animals subjected to $24 \mathrm{~h}$ of water restriction. The amount of fatty acids in the meat presented little variation due to the water restriction periods, however, there was an increase in EPA and a reduction in CLA and DHA, important for human health. The indices of atherogenicity and thrombogenicity were not affected by water restriction.

This study demonstrates that is possible produce carcass and meat with quality through feedlot lamb in semi-arid region, during the dry season, where do you have severe water shortage, using water restriction intervals up to $24 \mathrm{~h}$. The interval of $24 \mathrm{~h}$ of water restriction promoted the highest similarities in the characteristics assessed compared to those in animals receiving water ad libitum. Thus, water restriction periods should not exceed $24 \mathrm{~h}$ and may be used to reduce water intake by feedlot sheep in situations extreme water shortage.

\section{Acknowledgements}

This study was financed by the Foundation of Support for Science and Technology of the State of Pernambuco (FACEPE) - APQ.1689$5.04 / 12$

\section{References}

Abioja, M. O., Osinowo, O. A., Adebambo, O. A., Bello, N. J., \& Abiona, J. A. (2010) Water restriction in goats during hot-dry season in the humid tropics: Feed intake and weight gain. Archivos de Zootecnia, 59, 195-203.

Alamer, M. (2006). Physiological responses of Saudi Arabia indigenous goats to water deprivation. Small Ruminant Research, 63, 100-109.

Alamer, M. (2009). Effect of water restriction on lactation performance of Aardi goats under heat stress conditions. Small Ruminant Research, 84, 76-81.

Alamer, M. (2010). Effect of water restriction on thermoregulation and some biochemical constituents in lactating Aardi goats during got weather conditions. Scientific Journal of King Faisal University (Basic and Applied Sciences), 11, 189-205.

Alamer, M., \& Al-hozab, A. (2004). Effect of water deprivation and season on feed intake, body weight and thermoregulation in Awassi and Najdi sheep breeds in Saudi Arabia. Journal of Arid Environments, 59, 71-84.

AOAC (2007). Official methods of analysis, 18th edition Association of Official Analytical Chemists (AOAC). (Washington, DC, USA).

AOCS (2009). Official Method Am 5-04 - Rapid Determination of oil/fat Utilizing high Temperature Solvent extraction. Additions and Revisions to the Official Methods and Recommended Pratices of the AOCS (6th ed.). (Denver).

Atti, N., Mahouachi, M., \& Rouissi, H. (2006). The effect of spineless cactus (Opuntia ficusindica $f$. inermis) supplementation on growth, carcass, meat quality and fatty acid composition of male goat kids. Meat Science, 73, 229-235.

Barbour, E., Rawda, N., Banat, G., Jaber, L., Sleiman, F. T., \& Hamadeh, S. (2005). Comparison of immunosuppression in dry and lactating Awassi ewes due to water deprivation stress. Veterinary Research Communications, 29, 47-60.

Baumgard, L. H., Sangster, J. K., \& Bauman, D. E. (2001). Milk fat synthesis in dairy cows is progressively reduced by increasing supplemental amounts of trans-10, cis-12 conjugated linoleic acid. The Journal of Nutrition, 131, 1764-1769.

Boccard, R., \& Dumont, B. L. (1960). Etude de la production de la viande chez les ovins. II variation de l'importance relative des differents régions corporelles de l'agneau de boucherie. Annales de Zootechnie, 9, 355-365.

Brasil (1997). Ministério da Agricultura. Departamento Nacional de Inspeção de Produtos de Origem Animal. Regulamento da Inspeção Industrial e Sanitária de Produtos de Origem Animal - RIISPOA. Brasília-DF: Ministério da Agricultura.

Burgos, M. S., Langhans, W., \& Senn, M. (2000). Role of rumen fluid hypertonicity in the dehydration-induced hypophagia of cows. Physiology \& Behavior, 71(3-4), 423-430.
Calder, P. (2006). N-3 polyunsaturated fatty acids, inflammation, and inflammatory diseases. The American Journal of Clinical Nutrition, 83, 1505-1519.

Camilo, D. A., Pereira, E. S., Pimentel, P. G., Costa, M. R. G. F., Mizubuti, I. Y., Ribeiro, E L. A., ... Moreno, G. M. B. (2012). Weight and yield of non-carcass components of Morada Nova lambs fed with different levels of metabolizable energy. Agricultural Sciences, 33, 2429-2440.

Carragher, J. F., \& Matthews, L. R. (1996). Animal behavior and stress: Impacts on meat quality. Proceedings of the New Zealand Society of Animal Production. Vol. 56. Proceedings of the New Zealand Society of Animal Production (pp. 162-216).

Cartaxo, F. Q., Cezar, M. F., Sousa, W. H., Gonzaga Neto, S. G., Pereira Filho, J. M. P., \& Cunha, M. G. G. (2009). Quantitative traits of carcass from lambs finished in feedlot system and slaughtered at different body conditions. Revista Brasileira de Zootecnia, $38,697-704$.

Casamassima, D., Pizzo, R., Palazzo, M., D'Alessandro, A. G., \& Martemucci, G. (2008). Effect of water restriction on productive performance and blood parameters in comisana sheep reared under intensive condition. Small Ruminant Research, 78, 169-175.

Cezar, M. F., \& Sousa, W. H. (2007). Carcaças Ovinas e Caprinas: Obtenção-avaliaçãoclassificação (pp. 232). Uberaba: Agropecuária Tropical.

Christie, W. (1982). A simple procedure for rapid transmethilation of glycerolipids and cholesterol esters. Journal of Lipid Research, 23, 1072.

Church, D. C. (1976). Anatomy of the stomach of ruminants and pseudoruminants. In D. C. Church (Ed.). Digestive Physiology and Nutrition of Ruminants (pp. 7-33). (2th ed.) (Metropolitan Printing, O. S. U., Book Stores, Corvallis, Oregon).

Clarke, S. D. (2001). Polyunsaturated fatty acid regulation of gene transcription: A molecular mechanism to improve the metabolic syndrome. The Journal of Nutrition, 131, 1129-1132.

Drouillard, J. S., Klopfenstein, T. J., Britton, R. A., Bauer, M. L., Gramlich, S. M., Wester, T. J., \& Ferrell, C. L. (1991). Growth, body composition, and visceral organ mass and metabolism in lambs during and after metabolizable protein or net energy restrictions. Journal of Animal Science, 69, 3357-3375.

Hamadeh, S. K., Rawda, N., Jaber, L. S., Habre, A., Abi Said, M., \& Barbour, E. K. (2006). Physiological responses to water restriction in dry and lactating Awassi ewes. Livestock Science, 101, 101-109.

Hamm, R. (1986). Functional properties of the miofibrillar system and their measurement. In P. J. Bechtel (Ed.). Muscle as Food (pp. 135-199). Orlando: Academic Press.

Hara, A., \& Radin, N. S. (1978). Lipid extraction of tissues with low-toxicity solvent. Analitical Biochemistry, 90, 420-426.

Henchion, M., McCarthy, M., Resconi, V. C., \& Troy, D. (2014). Meat consumption: Trends and quality matters. Meat Science, 98, 561-568.

Jaber, L. S., Habre, A., Rawda, N., Barbour, E. K., \& Hamadeh, S. (2004). The effect of water restriction on certain physiological parameters in Awassi sheep. Small Ruminant Research, 54, 115-120.

Jiménez Colmenero, F. (1996). Technologies for developing low-fat meat products. Trends in Food Science \& Technology, 7, 41-48.

Kaliber, M., Koluman, N., \& Silanikove, N. (2015). Physiological and behavioral basis for the successful adaptation of goats to severe water restriction under hot environmental conditions. Animal, 10, 1-7.

Kamalzadeh, A., Koops, W. J., Van Bruchem, J., \& Brangma, G. A. (1998). Effect of duration of feed quality restriction on body dimensions in lambs. Journal of Animal Science, 76, 735-742.

Kremer, R., Lorenzi, P., \& Barbato, G. (1989). Análisis del crecimiento de corderos Corriedale y su limitante nutricional en un sistema de producción tradicional. Veterinaria, 25, 3-11.

Madruga, M. S., Vieira, T. R. L., Cunha, M. G. G., Pereira Filho, J. M. P., Queiroga, R. C. R. E., \& Sousa, W. H. (2008). Effect of diets with increasing levels of whole cotton seed on chemical composition and fatty acid profile of Santa Inez (Santa Inês) lamb meat. Revista Brasileira de Zootecnia, 37, 1496-1502.

Maloiy, G. M. O., Kanui, T. I., Towett, P. K., Wambugu, S. N., Miaron, J. O., \& Wanyoike, M. M. (2008). Effects of dehydration and heat stress on food intake and dry matter digestibility in east African ruminants. Comparative Biochemistry and Physiology, 151, 185-190.

Misra, A., \& Singh, K. (2002). Effect of water deprivation on dry matter intake, nutrient utilization and metabolic water production in goats under semi-arid zone of India. Small Ruminant Research, 46, 159-165.

Munasinghe, D. M. S., \& Sakai, T. (2004). Sodium chloride as a preferred protein extractant for pork lean meat. Meat Science, 67, 697-703.

Naves, L. A., Vilar, L., Costa, A. C. F., Domingues, L., \& Casulari, L. A. (2003). Disorders in the secretion and action of antidiuretic hormone. Brazilian Archive of Endocrinology \& Metabolism, 47, 467-481.

NRC (2007). National Research Council. Nutrients requirements of Small Ruminants. 362p.Washington, D. C: National Academy Press.

Nuernberg, K., Nuernberg, G., Ender, K., Lorenz, S., Winkler, K., Rickert, R., \& Steinhart, H. (2002). N-3 fatty acids and conjugated linoleic acids of longissimus muscle in beef cattle. European Journal of Lipid Science and Technology, 104(8), 463-471.

Osório, J. C. S., Oliveira, N. M., Osório, M. T. M., Jardim, R. D., \& Pimentel, M. A. (2002). Meat production in male lambs derived from the crossing between border Leicester rams with Corriedale and Polwarth ewes. Revista Brasileira de Zootecnia, 31 , 1469-1480.

Park, Y., Storkson, J. M., Ntambi, J. M., Cook, M. E., Sih, C. J., \& Pariza, M. W. (2000). Inhibition of hepatic stearoyl-CoA desaturase activity by trans-10, cis-12 conjugated linoleic acid and its derivatives. Biochimica et Biophysica Acta, 1486, 285-292.

Pawlosky, R. J., Hibbeln, J. R., Lin, Y., Goodson, S., Riggs, P., Sebring, N., ... Salem, N. J. (2003). Effects of beef- and fish-based diets on the kinetics of $n-3$ fatty acid metabolism in human subjects. The American Journal of Clinical Nutriton, 77, 565-572.

Ponnampalam, E. N., Kerr, M. G., Butler, K. L., Cottrell, J. J., Dunshea, F. R., \& Jacobs, J. 
L. (2018). Filling the out of season gaps for lamb and hogget production: Diet and genetic influence on carcass yield, carcass composition and retail value of meat. Meat Science, 148, 156-163.

Ramakrishnan, U., Stein, A. D., Parra-Cabrera, S., Wang, M., Imhoff-Kunsch, B., JuarezMarquez, S., ... Martorell, R. (2010). Effects of docosahexaenoic acid supplementation during pregnancy on gestational age and size at birth: Randomized, doubleblind, placebo-controlled trial in Mexico. Food and Nutrition Bulletin, 31, 108-116.

Reis, W., Jobim, C. C., Macedo, F. A. F., Martins, E. N., Cecato, U., \& Silveira, A. (2001). Performance of feedlot lambs fed high-moisture grain corn silage or reconstitued grain corn silage in replacement of dry corn grain in the diet. Revista Brasileira de Zootecnia, 30, 525-532.

Ribeiro, R. D. X., Oliveira, R. L., Macome, F. M., Bagaldo, A. R., Silva, M. C. A., Ribeiro, C. V. D. M., .. Lanna, D. P. D. (2011). Meat quality of lambs fed on palm kernel meal, a by-product of biodiesel production. Asian-Australasian Journal of Animal Sciences, 24, 1399-1406.

Rosa, G. T., Pires, C. C., Silva, J. H. S., \& Motta, O. S. (2002). Proportions and coefficients of growth components, non-carcass of the live weight of male and female lambs under different feeding methods. Revista Brasileira de Zootecnia, 31, 2290-2298.

Safari, E., Fogarty, N. M., Ferrier, G. R., Hopkins, L. D., \& Gilmour, A. (2001). Diverse lamb genotypes. 3. Eating quality and the relationship between its objective measurement and sensory assessment. Meat Science, 57, 153-159.

Sañudo, C., Enser, M. E., Campo, G. R., María, G., Sierra, I., \& Wood, J. D. (2000). Fatty acid composition and sensory characteristic of lamb carcasses from Britain and Spain. Meat Science, 54, 339-346.

Sañudo, C., \& Sierra, I. (1986). Calidad de la canal en la especie ovina. Ovino, 1, 127-153. Scollan, N. D., Choi, N. J., Kurt, E., Fisher, A. V., Enser, M., \& Wood, J. D. (2001). Manipulating the fatty acid composition of muscle and adipose tissue in beef cattle. British Journal of Nutrition, 85, 115-124.

Silanikove, J. (1992). Effects of water shortage and hot environment on appetite and digestion in ruminants: A review. Livestock Production Science, 30, 175-193.

Silanikove, N. (1989). Interrelationships between water, food and digestible energy intake in desert and temperate goats. Appetite, 12, 163-170.

Smith, S. B., Gill, C. A., Lunt, D. K., \& Brooks, M. A. (2009). Regulation of fat and fatty acid composition in beef cattle. Asian-Australasian Journal of Animal Sciences, 22, 1225-1233.

Smith, W. L. (2007). Nutritionally essential fatty acids and biologically indispensable cyclooxygenases. Trends in Biochemical Sciences, 1, 27-37.

Sniffen, C. J., O'Connor, J. D., Van Soest, P. J., Fox, D. G., \& Russell, J. B. (1992). A net carbohydrate and protein system for evaluating cattle diets: II. Carbohydrate and protein availability. Journal of Animal Science, 70, 3562-3577.

Souza, D. A., Selaive-Villarroel, A. B., Pereira, E. S., Osório, J. C. S., \& Texeira, A. (2013) Growth performance, feed efficiency and carcass characteristics of lambs produced from Dorper sheep crossed with Santa Inês or Brazilian Somali sheep. Small Ruminant Research, 114, 51-55.

Tapiero, H., Nguyen Ba, G., \& Couvreur, P. (2002). Polyunsaturated fatty acids (PUFA) and eicosanoids in human health and pathologies. Biomedicine and Pharmacotherapy, 56, 215-222.

Taylor, C. R., Spinage, C. A., \& Lyman, C. P. (1969). Water relations of the waterbuck, an east African antelope. American Journal of Physiology, 217, 630-634.

Tibin, M. A. M., Bushara, I., Elemam, M. B., Tibin, I. M., \& Jadalla, J. B. (2012). Carcass characteristics of desert sheep under range conditions in North Kordofan state, Sudan. Online Journal of Animal and Feed Research, 2, 439-444.

Ulbricht, T. L. V., \& Southgate, D. T. A. (1991). Coronary heart disease: Seven dietary factors. Lancet, 338, 985-992.

Urbano, S. A., Ferreira, M. A., Júnior Dutra, W. M., Andrade, R. P. X., Siqueira, M. C. B., \& Félix, S. C. R. (2013). Carcass characteristics of sheep fed with castor bean hulls in replacement of Tifton 85 hay. Ciência e Agrotecnologia, 36, 85-93.

Van Nevel, C. J., \& Demeyer, D. I. (1996). Influence of pH on lipolysis and biohydrogenation of soybean oil by rumen contents in vitro. Reproduction Nutrition Development, 36, 53-63.

Van Soest, P. J., Robertson, J. B., \& Lewis, B. A. (1991). Methods for dietary fiber, neutral detergent fiber and non - starch polysaccharides in relation to animal nutrition. Journal of Dairy Science, 74, 3583-3597.

Zeola, N. M. B. L., Silva Sobrinho, A. G., Gonzaga Neto, S., \& Marques, C. A. T. (2004). Centesimal composition of the meat of lambs submitted to diets with different levels of concentrate. Ciência Rural, 34, 253-257. 